POSTER

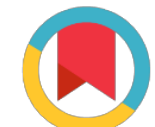

Check for updates
*For correspondence:

pvphuc@hcmus.edu.vn

Competing interests: The authors declare that no competing interests exist.

Received: 2017-02-07

Accepted: 2017-08-19

Published: 2017-05-09

Copyright The Author(s) 2017. This article is published with open access by BioMedPress (BMP).

This article is distributed under the terms of the Creative Commons Attribution License (CC-BY 4.0) which permits any use, distribution, and reproduction in any medium, provided the original author(s) and the source are credited.

\section{Sodium citrate induces apoptosis in HepG2 cell lines}

\author{
Sinh Truong Nguyen ${ }^{1,2}$, Phuc Hong Vo², Oanh Thi-Kieu Nguyen ${ }^{1,2}$, Nghia Minh \\ Do $^{2}$, Phuc Van Pham ${ }^{1,2 *}$ \\ ${ }^{1}$ Stem Cell Laboratory Research and Application, University of Science, Vietnam National \\ University HCMC, Ho Chi Minh City, Vietnam \\ ${ }^{2}$ Cancer Research Laboratory, University of Science, Vietnam National University HCMC, Ho Chi \\ Minh City, Vietnam
}

\section{Abstract}

PURPOSES: Cancer cells were observed to increase glucose uptake and fermentation of glucose to lactate to to synthesis rapidly ATP for cell growth, survival and proliferation. Thus, inhibition of glycolysis might be useful in antitumor treatment. This phenomenon occurred even with fully functioning mitochondria, and known as Warberg effect. Sodium citrate, an inhibitor of Warberg effect, was reported to antiproliferate many cancer cells line. However, sodium citrate has not been studied in Hepatocellular Carcinoma cells line yet. Here we aimed to investigate the effect of sodium citrate in HepG2 cells line.

MATERIAL AND METHODS: HepG 2 cell lines was treated with sodium citrate at different concentrations. Viable cells were determined by Alamar Blue. The apoptosis induced-cells was detected by Annexin $\vee$ with FCM technique. Disintegrated nuclei and DNA fragmentation was analyzed. The activity of caspase-3 was also tested.

RESULTS: We observed that the $\mathrm{IC}_{50}$ value of sodium citrate on $\mathrm{HepG}_{2}$ is at $10 \mathrm{mM}$. FCM analysis showed that sodium citrate induced apoptosis in HepG 2 cell line in dose-dependent manner. At 1omM sodium citrate, the caspase-3/7 was observed to be activated in timedependent manner. Sodium citrate also induced nuclei disintergated in HepG2. DNA fragmentation was observed when HepG2 cells were treated with $10 \mathrm{mM}$ sodium citrate.

CONCLUSIONS: We have shown that sodium citrate possesses the antiproliferative ability on HepG2 at IC 50 10mM. Sodidum citrate induces apoptosis cells in hepatocellular carcinoma HepG 2 by capases-3 activation. More investigation of glycolysis inhibition of sodium citrate on HepG2 should be performed in animals

\section{Keywords}

Apoptosis, caspase-3/7, glycolysis, HepG2, sodium citrate

Funding

Project A2015-18-01, VNU-HCM

\section{References}

